\title{
Personality changes in HIV-infected patients who have been receiving highly active antiretroviral therapy
}

Paweł P. Dobrakowski, Sebastian Skalski

Institute of Psychology, Humanitas University in Sosnowiec, Poland

\begin{abstract}
Introduction: The major objective of this paper was to search for personality changes in people diagnosed with human immunodeficiency virus (HIV) as well as to investigate their level of self-esteem, psychosocial benefits, and cognitive appraisal of the infection. We have also analysed how the subjective appraisal of the infection correlates with personality traits, the level of psychosocial benefits, and variables related to antiretroviral therapy (ARV).

Material and methods: The study involved $32 \mathrm{HIV}$-infected patients who had been receiving highly active antiretroviral therapy (HAART). Research tools used: Adjective Check List (ACL), Silver Lining Questionnaire (SL-24), Disease-Related Appraisals Scale (DRAS), and our own questionnaire used to obtain socio-demographic information and data related to ARV therapy.

Results: The study proved there are statistically significant differences between the Actual self and the Retrospective self profiles regardig the need for change, submission, and the Adapted Child ego. The level of self-esteem in HIV-infected patients emerged po be sinificantly lower when compared to other clinical control groups. Patients with HIV reported psychosocial benefits regarding their life philosophy, improved character strength, and improved interpersonal relationships. The cognitive appraisal of the HIV infection correlated significantly with certain personality traits as well as the level of psychosocial benefits, the duration of ARV therapy, and the CD4 cell count.

Conclusions: The diagnosis of HIV infection may cause personality changes in the affected person. HIV-infected patients have a low level of self-esteem. Also, they may experience post-traumatic growth. People infected with HIV create a subjective (cognitive) assessment of their situation, which proves to depend on their personality traits, the level of psychosocial benefits, and treatment-related variables.
\end{abstract}

HIV AIDS Rev 2019; 18, 3: 165-175 DOI: https://doi.org/10.5114/hivar.2019.88445

Key words: HIV, self-esteem, post-traumatic growth, personality changes, cognitive appraisal.

\section{Introduction}

There are nearly 37 million people infected with human immunodeficiency virus (HIV) [1]. In 2016, about one million people died from HIV/acquired immunodeficiency syndrome (AIDS). In Poland, the number of HIV infections has

been on the rise in recent years [2]. From 1985 (the beginning of the national research) until the $31^{\text {st }}$ of July 2017, there were 22,038 confirmed HIV infections [3]. According to epidemiologists, the number of infections in Poland is probably much higher as more than half of HIV-infected people are not aware of their serological status.

Article history:

Received: 11.12.2018

Received in revised form: 28.06.2019

Accepted: 28.06.2019

Available online: 13.09.2019
International Journal of HIV-Related Problem

HIV \& AIDS

R e v i e w 
Although over 35 years have passed since HIV was first linked with AIDS, there is still no vaccination available that would protect against the virus. Similarly, there are still no medications available that could eradicate the HIV virus. However, thanks to the introduction of highly active antiretroviral therapy (HAART) it is now possible to significantly slow down the progress of the infection and the development of AIDS. It is estimated that if a HIV-infected person starts receiving treatment at about the age of 20 , they may reach the age of 70 or more [4]. In such a situation, we deal with the phenomenon of aging HIV-infected people. Moreover, the epidemic itself is not limited to small, high-risk groups anymore. More and more frequently it affects heterosexual men and women as well as children. Due to a changing epidemiological situation, psychologists and therapists need to undertake new activities aimed at improving the quality of life and psychosocial functioning of people infected with HIV.

Trauma has been the most frequently examined psychological aspect of the HIV infection so far. It is connected with the feeling of fear, loss, sadness, helplessness, anger, aggression, and negation. Many HIV-infected patients mentioned the feeling of guilt and low self-esteem. The risk of a suicide attempt was also higher [5-8].

\section{Personality after the infection}

An individual's awareness of the HIV infection causes severe stress (traumatic), which affects their personality structure [9]. The most popular tools used to describe the HIV-infected person's personality traits are questionnaires based on the Big Five (NEO-FFI and NEO-PI-R). Previous studies on HIV-infected patients' personality focused on disorders that were connected with risky behaviours and bad health habits. Such correlations were found for neuroticism and impulsiveness $[10,11]$. Neuroticism (understood as depressed mood, anxiety, anger, and a low level of self-confidence) also contributed to the low quality of life of people infected with HIV $[12,13]$. Conversely, openness, extraversion, and conscientiousness seem to be connected with slower progression of the illness [14]. However, so far we have failed to find papers that tried to explain the correlation between one's awareness of being infected with HIV and changes to one's personality traits. In order to compare the condition of an individual before and after the infection, we needed a more flexible tool than NEO-FFI. The ACL test was a good choice here.

\section{Self-esteem}

Self-esteem is one's attitude towards oneself and one's capabilities [15]. According to Maslow, self-esteem is the basic need of human personality [16]. It defines our uniqueness and enables self-fulfilment and self-acceptance. It acts as a buffer that reduces the negative effects of stress [17]. Self-esteem plays an important role in coping, acts as a reservoir of feelings, and affects one's behaviour.

\section{Posttraumatic growth}

Experiencing a strong stress response due to a traumatic event may have positive effects on the structure of a person's personality. This phenomenon is called post-traumatic growth (PTG) and refers to changes that arise from trying to cope with a traumatic event. Post-traumatic growth is the result of various life situations and experiences, and a sign of one's maturity. It is not an adaptive mechanism, but rather a result of such adaptation. Such form of growth may include changes in self-perception, interpersonal relationships, or life philosophy, and results from remedial strategies employed by an individual [18].

Posttraumatic growth is characterised by three main aspects of the individual's functioning:

- changes in self-perception: this aspect refers to changes in current lifestyle, a higher level of self-trust, and belief in one's abilities;

- improved interpersonal relationships: this aspect refers to greater openness to others, deeper relationships, rationalization, and deeper empathy;

- changes in life philosophy: this aspect refers to revaluation of priorities, augmentation of existential needs, and spiritual (religious) development [19].

The occurrence of PTG is characteristic for life-threatening or health-threatening situations experienced by an individual [20]. PTG may co-occur with PTSD [21].

The occurrence of PTG depends on remedial strategies employed by an individual. The triggering strategies are: social support, meaning-based coping, and targeted coping $[18,22]$. The occurrence of PTG is also determined by one's personality traits and the nature of the stressful situation itself [19].

\section{Illness perception}

Illness perception is defined as a patient's beliefs and expectations towards the illness or related somatic symptoms. The way patients perceive their illness may influence the development of PTG [23]. Processing of trauma-related associations (such as evaluation, adaptation, and creation of meanings) is a potential mechanism of PTG creation [24].

According to Lazarus and Folkman, cognitive appraisal plays an important role in the stress relationship. What is more, it is the original cognitive appraisal that determines whether a stress reaction occurs or not [25]. Perceiving a given situation as neutral or positive does not affect the existing adaptation mechanisms, and hence does not constitute a source of stress. Perceiving a given situation as dangerous, harmful, or challenging triggers changes in an individual's existing adaptation mechanisms and initiates the onset of stress reaction and determination of coping methods.

In relation to health problems, cognitive appraisal is analysed with two aspects in mind. The first aspect is the subjective sense and meaning of the illness in one's life [25, 26], while the second aspect creates a system of beliefs and knowledge about the illness [27]. In this paper, the cognitive 
appraisal of the HIV infection was understood according to the theory proposed by Lazarus and Folkman.

The aim of this paper is to answer the following questions:

- Can one's awareness of the HIV infection affect one's personality?

- Can the HIV infection affect one's self-esteem?

- Can post-traumatic growth occur in infected people?

- Can people infected with HIV perceive their condition in terms of benefits and values?

- Can people infected with HIV perceive the very infection in terms of benefits and values?

\section{Material and methods}

\section{Participants}

The study was conducted in the autumn of 2018 in two Polish voivodships: Silesia and Lesser Poland. The study involved $32 \mathrm{HIV}$-infected patients who had been receiving HAART therapy. Information about the undergoing study was spread through acquired immunodeficiency clinics as well as organisations helping people with HIV/AIDS. Prior to receiving the questionnaire, every participant granted consent to participate in the study and personal data processing. A detailed structure of the treatment group is shown in the table below (Table 1).

$40.6 \%$ of the participants had been aware of the HIV infection for less than two years $(n=13)$, and $59.4 \%$ of the participants had been aware of the HIV infection for more than two years $(n=19) .46 .9 \%$ of the study participants had been treated with anti-retroviral therapy (ARV) for less than two years $(n=15)$, and $53.1 \%$ of study participants had been treated for longer than two years $(n=17)$. The implemented categories allow the diversification of short-term and longterm effects of trauma.

The participants were also assessed based on parameters related to antiretroviral therapy. A vast majority of the participants $(81.3 \%)$ declared undetectable viraemia $(n=26) .18 .7 \%$ of the participants declared detectable viremia $(n=6)$. Each participant's CD4 cell count in one millilitre of blood was checked according to the most recent laboratory test. In $59.4 \%$ of the participants, the CD4 cell count was above $350 / \mu \mathrm{l}(n=19)$. Such a level significantly limits the risk of HIV-related diseases and infections [28]. In $40.6 \%$ of the participants, the $\mathrm{CD}_{4}$ cell count was below $350 / \mu \mathrm{l}(n=13)$.

\section{Tools}

\section{Personality traits and self-esteem examination}

In order to analyse changes in personality traits caused by the HIV infection in people undergoing HAART therapy, we used the Adjective Check List (ACL) by Harrison, Gough, and Heilbrun [29]. The Polish translated version of the test was used (translation by Płużek). ACL is used to diagnose the personality structure of an individual, especially in rela-
Table 1. Structure of the studied group $(n=32)$

\begin{tabular}{|c|c|c|}
\hline Factor & $n$ & $\%$ \\
\hline \multicolumn{3}{|l|}{ Sex } \\
\hline Male & 12 & 37.5 \\
\hline Female & 20 & 62.5 \\
\hline \multicolumn{3}{|l|}{ Age (years) } \\
\hline$<20$ & 3 & 9.3 \\
\hline $21-30$ & 10 & 31.3 \\
\hline $31-40$ & 14 & 43.8 \\
\hline $41-50$ & 2 & 6.3 \\
\hline$>50$ & 3 & 9.3 \\
\hline \multicolumn{3}{|l|}{ Educational level } \\
\hline Primary education & 1 & 3.1 \\
\hline Vocational education & 3 & 9.4 \\
\hline Secondary education & 12 & 37.5 \\
\hline Higher education & 16 & 50.0 \\
\hline \multicolumn{3}{|l|}{ Marital status } \\
\hline Single & 15 & 46.9 \\
\hline Married & 8 & 25.0 \\
\hline Cohabitant & 9 & 28.1 \\
\hline Divorced & 0 & 0 \\
\hline Widowed & 0 & 0 \\
\hline \multicolumn{3}{|l|}{ Place of living } \\
\hline Rural area & 2 & 6.3 \\
\hline Town $<30,000$ citizens & 4 & 12.4 \\
\hline Town $30,000-100,000$ citizens & 6 & 18.8 \\
\hline City $>100,000$ citizens & 20 & 62.5 \\
\hline \multicolumn{3}{|l|}{ Sexual preferences } \\
\hline Heterosexual & 18 & 56.2 \\
\hline Bisexual & 2 & 6.3 \\
\hline Homosexual & 12 & 37.5 \\
\hline
\end{tabular}

tion to the individual's needs and self-perception. The ACL checklist contains 300 adjectives from which the examined person choses those that (in their opinion) best suite their self-report. The tool is flexible, and its instructions can be adjusted. As such, it can be used to examine personality traits in retrospective, realistic, and ideal profiles. The ACL scales consist of five parts. The first scale (modus operandi) describes the examined person's attitude, i.e. the way they articulate and describe. The second scale refers to personality correlates, i.e. mental and behavioural needs according to Murray's theory. The third scale shows topical needs and involves behavioural aspects in interpersonal relationships. The fourth scale shows the transactional analysis scales according to Berne's theory. The fifth scale consists of creativity and intelligence scales according to Welsh's theory [30]. The reliability coefficient (Cronbach's $\alpha$ ) for individual scales is between 0.53 and 0.95 . We decided to use two question- 
naires for the test: one to create the current self-image (the so-called Actual self) and the other to create the self-image before the HIV infection (the so-called Retrospective self). To avoid choosing the same adjectives by the participants, the questionnaires were interwoven with other research tools. In order to create the profiles, raw scores were converted to T-score scale results using norm tables relevant to sex and the number adjectives chosen [31]. The converted results that were within the range of 35-65 points fell within the norm, i.e. within the so-called diagnostic silence. $T$-score scale results below 35 points were considered low, and those above 65 points were considered high.

\section{Posttraumatic growth}

The Silver Lining Questionnaire by Sodergren and Hyland (SL-24) in the Polish translation by Kossakowska is a tool used to examine the psychosocial benefits of the illness $[32,33]$. It measures five positive aspects of the illness:

- improved interpersonal relationships,

- appreciation for life,

- positive influence on others,

- personal inner strength,

- changes in life philosophy.

During the examination, participants express their opinion on 24 statements using a five-point scale, where 5 points means strongly agree and 1 point means strongly disagree. Values 5 and 4 are treated as 1 , and values 3, 2, and 1 are treated as 0 . In this way it is possible to count the number of declared psychosocial benefits resulting from the illness. For the needs of our research and statistical analyses (in order to compare benefits in individual scales), we calculated the mean, which takes a value from 0 to 1 . Values above 0.5 suggest a psychosocial benefit. The reliability coefficient (Cronbach's $\alpha$ ) for the whole tool is 0.93 [32].

\section{Illness perception}

The Disease-Related Appraisals Scale (DRAS) by Janowski and Steuden is used to subjectively examine how a given person perceives their health problems [34]. The questionnaire is based on the assumptions of the original cognitive appraisal (according to the transactional model of stress by Lazarus and Folkman) and also refers to the illness perception categories by Lipowski $[25,26]$. The tool consists of 47 elements that make up seven subscales:

- threat: refers to destabilising one's current life situation due to the illness,

- profit: refers to secondary benefits from the illness,

- obstacle/loss: refers to everyday life limitations imposed by the illness,

- challenge: refers to motivation to fight off the illness,

- harm: illness perceived as undeserved punishment,

- value: illness as an opportunity for internal mental development,

- importance: signifies the importance of the illness in one's life.
During the examination, the participants express their opinion on 47 statements using a five-point scale: yes, rather yes, don't know, rather not, no. Each statement is rated from 1 (no) to 5 (yes). The higher the result in a given subscale, the more subjective the illness appraisal is. The scale offers satisfactory accuracy and reliability, which was confirmed by the Cronbach's a coefficient's values (ranging from 0.64 to 0.87 for individual subscales).

\section{Statistical analysis}

Results obtained from the empirical research were statistically analysed using PSPP 1.0.1. software (GNU license).

To calculate the significance of differences between means in the same treatment group, we used Student's $t$-test for the dependent sample. When comparing means in two treatment groups, the significance of differences was measured using Student's $t$-test for the independent sample. We calculated the Pearson $r$ correlation coefficient to analyse covariance between the data. The effect size based on means was verified using Cohen's $d$. Due to the disproportion between the groups' sizes, in order to calculate the significance of differences in the Disease-Related Appraisals Scale (DRAS) between the results in the treatment group and the mean results of somatically ill patients, we used Student's $t$-test for one sample.

We assumed a statistically significant difference to be $p<0.05$, and a large effect size to be Cohen's $d>0.8$. We assumed a large correlation to be $r>0.7$, and medium correlation to be $r>0.4$.

\section{Results}

\section{Personality changes}

Below are mean results from the needs scales, topical scales, and transactional analysis scales, with standard deviation included. In addition, Table 2 shows the difference between the realistic and retrospective profile.

Mean results from the Actual self that were considered particularly low were obtained in the following scales: Int (the need for self-understanding and understanding others), Nur (the need for nurturing others), and Fem (femininity). The mean result that was considered particularly high was obtained in the Free Child (FC) scale.

Mean results from the Retrospective self that were considered particularly low were obtained in the following scales: Int (the need for self-understanding and understanding others), Nur (the need for nurturing others), Mls (the need for leadership), and Fem (femininity). The mean result that was considered particularly high was obtained in the Free Child (FC) scale.

Statistically significant differences (with a large effect size between the Actual self and the Retrospective self) were shown for the following scales: Cha (the need for change), Def (the need for submission), and AC (Adapted Child). 
Table 2. Significance of differences in Adjective Check List (ACL) scores due to HIV awareness $(n=32)$

\begin{tabular}{|c|c|c|c|c|c|c|c|}
\hline \multirow[t]{2}{*}{$\mathrm{ACL}$} & \multicolumn{2}{|c|}{ Real self $(n=32)$} & \multicolumn{2}{|c|}{ Retrospective self $(n=32)$} & \multirow[t]{2}{*}{$t$} & \multirow[t]{2}{*}{ Mean diff. } & \multirow[t]{2}{*}{$d$ Cohen's } \\
\hline & M & SD & M & SD & & & \\
\hline \multicolumn{8}{|c|}{ Need scales } \\
\hline Ach - Achievement & 39.22 & 5.65 & 41.38 & 6.36 & $-2.08^{*}$ & -2.16 & 0.36 \\
\hline Dom - Dominance & 44.06 & 4.20 & 44.91 & 4.76 & -0.86 & -0.85 & 0.15 \\
\hline End - Endurance & 38.72 & 5.48 & 38.34 & 4.74 & 0.33 & 0.38 & -0.06 \\
\hline Ord-Order & 39.06 & 17.35 & 38.16 & 19.02 & 0.58 & 0.90 & -0.10 \\
\hline Int - Intraception & 25.78 & 6.56 & 29.69 & 7.43 & $-2.84^{\star *}$ & -3.91 & 0.50 \\
\hline Nur - Nurturance & 30.63 & 4.08 & 30.81 & 5.59 & -0.16 & -0.18 & 0.02 \\
\hline Aff - Affiliation & 31.81 & 7.75 & 31.66 & 8.02 & 0.12 & 0.15 & -0.02 \\
\hline Het - Heterosexuality & 33.72 & 8.18 & 35.09 & 6.53 & -0.81 & -1.37 & 0.14 \\
\hline Exh - Exhibition & 51.16 & 5.75 & 52.75 & 5.30 & -1.60 & -1.59 & 0.28 \\
\hline Aut - Autonomy & 55.26 & 6.04 & 57.09 & 5.94 & -1.63 & -1.83 & 0.29 \\
\hline Agg - Aggression & 54.00 & 3.62 & 56.75 & 5.41 & $-2.77^{\star \star}$ & -2.75 & 0.49 \\
\hline Cha - Change & 37.00 & 6.78 & 43.16 & 7.95 & $-3.60^{* * *}$ & -6.16 & 0.64 \\
\hline Suc-Succorance & 49.28 & 8.46 & 51.41 & 7.43 & -1.20 & -2.13 & 0.21 \\
\hline Aba - Abasement & 51.22 & 5.53 & 49.22 & 5.27 & 1.73 & 2.00 & -0.31 \\
\hline Def - Deference & 46.34 & 4.51 & 40.88 & 4.44 & $5.26^{\star * *}$ & 5.46 & -0.93 \\
\hline \multicolumn{8}{|c|}{ Topic scales } \\
\hline Crs - Counselling readiness & 58.63 & 5.52 & 57.50 & 4.54 & 1.24 & 1.13 & -0.22 \\
\hline S-Cn - Self-control & 49.84 & 5.41 & 48.00 & 4.81 & 1.79 & 1.84 & -0.32 \\
\hline S-Cfd - Self-confidence & 39.88 & 5.30 & 39.16 & 5.06 & 0.73 & 0.72 & -0.13 \\
\hline P-Adj - Personal adjustment & 33.75 & 6.47 & 33.91 & 6.01 & -0.12 & -0.16 & 0.02 \\
\hline Iss - Ideal self & 46.84 & 6.10 & 43.84 & 5.05 & $3.16^{\star \star}$ & 3.00 & -0.56 \\
\hline Cps - Creative personality & 43.53 & 8.10 & 44.94 & 9.07 & -0.71 & -1.41 & 0.13 \\
\hline Mls - Military leader & 31.44 & 7.10 & 30.59 & 7.54 & 0.62 & 0.85 & -0.11 \\
\hline Mas - Masculine & 47.72 & 10.22 & 46.34 & 8.35 & 0.69 & 1.38 & -0.12 \\
\hline Fem - Femininity & 26.81 & 9.01 & 28.06 & 10.07 & -0.83 & -1.25 & 0.15 \\
\hline \multicolumn{8}{|c|}{ Transactional analysis scales } \\
\hline $\mathrm{CP}-$ Critical parent & 55.34 & 7.02 & 54.44 & 5.55 & 0.69 & 0.90 & -0.12 \\
\hline NP - Nurturing parent & 34.75 & 5.89 & 34.22 & 5.77 & 0.50 & 0.53 & -0.09 \\
\hline A - Adult & 38.50 & 14.39 & 40.81 & 15.60 & $-2.85^{\star \star}$ & -2.31 & 0.50 \\
\hline FC - Free child & 73.16 & 14.98 & 76.94 & 15.65 & $-2.89^{\star *}$ & -3.78 & 0.51 \\
\hline AC - Adapted child & 59.66 & 6.30 & 55.31 & 3.64 & $3.42^{* *}$ & 4.35 & -0.60 \\
\hline
\end{tabular}

${ }^{{ }^{*} p} \leq 0.05,{ }^{* *} p \leq 0.01,{ }^{* * *} p \leq 0.001 ; t$-Student's t-test

\section{Self-esteem level}

The ACL questionnaire was also used to determine the self-esteem level in HIV-infected patients who had been receiving HAART therapy. The self-esteem index was calculated using the following formula: $s=\mathrm{Fav} / \mathrm{Unfav}$, where Fav is the number of positive adjectives, and Unfav is the number of negative adjectives that were used to describe a given person in the real self-image (Actual self). The self-esteem index of the treatment group was 0.37 .

\section{Psychosocial benefits}

The participants reported greatest benefits in the area of personal inner strength, improved interpersonal relationships, and change in life philosophy (Table 3 ).

\section{The subjective image of the illness}

In order to verify how one's perception of the HIV infection correlates with their personality traits, the ACL test 
Table 3. Silver Lining Questionnaire (SL-24) descriptive statistics in HIV patients $(n=32)$

\begin{tabular}{l|c|c}
\hline SL-24 & M & SD \\
\hline Improved interpersonal relationships & 0.54 & 0.25 \\
\hline Appreciation for life & 0.39 & 0.36 \\
\hline Positive influence on others & 0.24 & 0.35 \\
\hline Personal inner strength & 0.64 & 0.3 \\
\hline Changes in life philosophy & 0.51 & 0.41 \\
\hline
\end{tabular}

results obtained from the Actual self-image and the DiseaseRelated Appraisals Scale were correlated.

The Threat subscale showed a statistically significant positive correlation with the $A C$ scale (adapted child), and a negative correlation with the following scales: $A g g$ (the need for aggression), P-Adj (personal adjustment), and Mas (masculinity).

The Profit subscale showed a statistically significant onlynegative correlation with the following scales: Int (the need

Table 4. The results in Adjective Check List (ACL) and Disease-Related Appraisals Scale (DRAS) - Pearson correlation coefficients in HIV patients $(n=32)$

\begin{tabular}{|c|c|c|c|c|c|c|c|}
\hline \multirow[t]{2}{*}{$\mathrm{ACL}$} & \multicolumn{7}{|c|}{ DRAS } \\
\hline & Threat & Profit & Obstacle/Loss & Challenge & Harm & Value & Importance \\
\hline \multicolumn{8}{|c|}{ Need scales } \\
\hline Ach & -0.11 & -0.15 & -0.25 & $0.35^{*}$ & -0.19 & -0.14 & 0.02 \\
\hline Dom & -0.18 & 0.11 & -0.16 & $0.46^{* *}$ & $-0.35^{*}$ & 0.21 & -0.12 \\
\hline End & 0.23 & -0.14 & 0.2 & -0.22 & 0.16 & -0.06 & 0.21 \\
\hline Ord & 0.05 & -0.12 & 0.08 & 0.13 & 0.09 & 0.12 & 0.16 \\
\hline Int & -0.03 & $-0.6^{* * *}$ & -0.04 & -0.3 & -0.13 & -0.3 & 0.04 \\
\hline Nur & 0.23 & -0.22 & 0.23 & -0.22 & 0.12 & -0.22 & 0.16 \\
\hline Aff & -0.24 & -0.21 & -0.18 & -0.03 & $-0.46^{* *}$ & -0.25 & -0.24 \\
\hline Het & 0.17 & -0.18 & 0.09 & -0.02 & 0.09 & 0 & 0.22 \\
\hline Exh & -0.11 & -0.08 & -0.16 & -0.03 & -0.14 & -0.08 & 0.1 \\
\hline Aut & -0.15 & 0.08 & $-0.47^{* *}$ & -0.11 & -0.17 & 0.23 & 0.03 \\
\hline Agg & $-0.35^{*}$ & 0.06 & -0.13 & 0.1 & -0.11 & 0.13 & -0.18 \\
\hline Cha & 0.06 & $-0.36^{\star}$ & 0.1 & 0.01 & -0.1 & -0.22 & 0.01 \\
\hline Suc & -0.23 & -0.02 & -0.22 & -0.02 & -0.11 & $-0.39^{*}$ & -0.15 \\
\hline Aba & -0.13 & -0.22 & -0.08 & -0.31 & -0.22 & $-0.56^{\star * *}$ & -0.19 \\
\hline Def & 0.08 & -0.11 & 0.16 & -0.18 & 0.05 & -0.25 & -0.14 \\
\hline \multicolumn{8}{|c|}{ Topic scales } \\
\hline Crs & 0.28 & 0.28 & 0.12 & 0.18 & $0.39^{*}$ & 0.17 & 0.07 \\
\hline $\mathrm{S}-\mathrm{Cn}$ & -0.01 & 0.07 & 0.04 & -0.17 & 0.03 & -0.19 & -0.14 \\
\hline S-Cfd & -0.02 & 0.06 & -0.07 & 0.08 & -0.06 & 0.19 & 0.08 \\
\hline P-Adj & $-0.38^{*}$ & -0.07 & -0.23 & 0.13 & $-0.38^{*}$ & 0.08 & $-0.41^{*}$ \\
\hline Iss & 0.02 & -0.17 & -0.03 & -0.18 & 0.05 & 0.09 & 0.15 \\
\hline Cps & -0.02 & -0.21 & -0.12 & 0.12 & -0.12 & 0.17 & -0.04 \\
\hline Mls & 0.02 & 0 & -0.02 & 0.06 & -0.08 & 0.23 & -0.06 \\
\hline Mas & $-0.36^{*}$ & 0.06 & -0.21 & 0.06 & -0.21 & $0.46^{* *}$ & -0.08 \\
\hline Fem & -0.08 & $-0.43^{*}$ & -0.04 & -0.06 & -0.24 & -0.21 & -0.1 \\
\hline \multicolumn{8}{|c|}{ Transactional analysis scales } \\
\hline $\mathrm{CP}$ & 0.11 & 0 & -0.02 & 0.02 & 0.22 & 0.24 & 0.26 \\
\hline NP & 0.21 & -0.22 & $0.37^{*}$ & -0.12 & 0.04 & -0.24 & 0.25 \\
\hline A & 0.08 & -0.15 & 0.11 & 0.12 & 0.13 & 0.11 & 0.2 \\
\hline FC & -0.08 & 0.08 & -0.09 & $-0.35^{*}$ & -0.14 & -0.2 & -0.15 \\
\hline$A C$ & $0.35^{*}$ & 0.24 & 0.13 & 0.07 & $0.39^{*}$ & 0.13 & $0.39^{*}$ \\
\hline
\end{tabular}


for self-understanding and understanding others), Cha (the need for change), and Fem (femininity).

The Obstacle/loss subscale showed a statistically significant positive correlation with the NP scale (nurturing parent), and a negative correlation with the Aut scale (the need for autonomy).

The Challenge subscale showed statistically significant positive correlations with the Ach (the need for achievements) and Dom (the need for domination) scales, and a negative correlation with the $F C$ scale (free child).

The Harm subscale showed statistically significant positive correlations with the Crs (counselling readiness) and $A C$ (adapted child) scales, and a negative correlation with the Dom (the need for domination), Aff (the need for affiliation), and $P$-Adj scale (personal adjustment) scales.

The Value subscale showed a statistically significant positive correlation with the Mas scale (masculinity), and a negative correlation with the following scales: Suc (the need for succour) and $A b a$ (the need for abasing oneself).

The Importance subscale showed a statistically significant positive correlation with the $A C$ scale (adapted child), and a negative correlation with the $P$-Adj scale (personal adjustment) (Table 4).

In order to verify how one's perception of the HIV infection correlates with psychosocial benefits, the results obtained from the Disease-Related Appraisals Scale and the Silver Lining Questionnaire (SL-24) were correlated (Table 5).

The Threat subscale showed a statistically significant positive correlation with Changes in life philosophy, and a negative correlation with the Appreciation for life scale.

The Profit subscale showed a statistically significant positive correlation with the following scales: Improved interpersonal relationships, Greater appreciation for life, Personal inner strength, and Changes in life philosophy.

The Challenge subscale showed a statistically significant positive correlation with each measured aspect of psychosocial benefits, i.e.: Improved interpersonal relationships, Greater appreciation for life, Positive influence on others, Personal inner strength, and Changes in life philosophy.

The Harm subscale showed a statistically significant positive correlation with Changes in life philosophy.

Table 5. The results in Disease-Related Appraisals Scale (DRAS) and Silver Lining Questionnaire (SL-24) - Pearson correlation coefficients in HIV patients $(n=32)$

\begin{tabular}{|c|c|c|c|c|c|c|c|}
\hline \multirow[t]{2}{*}{ SL-24 } & \multicolumn{7}{|c|}{ DRAS } \\
\hline & Threat & Profit & Obstacle/loss & Challenge & Harm & Value & Importance \\
\hline Improved interpersonal relationships & 0.15 & $0.64^{* * *}$ & 0.11 & $0.55^{* * *}$ & 0.25 & $0.61^{* * *}$ & -0.14 \\
\hline Appreciation for life & $-0.43^{*}$ & $0.61^{\star * *}$ & -0.21 & $0.41^{*}$ & -0.25 & $0.44^{*}$ & $-0.64^{* * *}$ \\
\hline Positive influence on others & -0.25 & 0.23 & -0.18 & $0.46^{* *}$ & 0.02 & $0.33^{*}$ & $-0.34^{*}$ \\
\hline Personal inner strength & 0.15 & $0.64^{* * *}$ & 0.22 & $0.52^{* *}$ & 0.25 & $0.61^{* * *}$ & -0.12 \\
\hline Changes in life philosophy & $0.36^{*}$ & $0.34^{\star}$ & 0.27 & $0.52^{\star \star}$ & $0.37^{*}$ & $0.67^{\star \star *}$ & 0.12 \\
\hline
\end{tabular}

Table 6. Disease-Related Appraisals Scale (DRAS) descriptive statistics in HIV patients $(n=32)$ and significance of differences in DRAS results depending on the parameters of antiretroviral treatment

\begin{tabular}{|c|c|c|c|c|c|c|c|}
\hline \multirow[t]{2}{*}{ Factor } & \multicolumn{7}{|c|}{ DRAS } \\
\hline & Threat & Profit & Obstacle/loss & Challenge & Harm & Value & Importance \\
\hline Total M (SD) & $24.69(8.37)$ & $13(4.13)$ & $18.97(8.06)$ & $20.44(5.25)$ & $17.22(8.14)$ & $14.66(6.43)$ & $17.34(5.15)$ \\
\hline \multicolumn{8}{|c|}{ Time of treatment } \\
\hline$<2$ years $M(S D)$ & $29.47(7.38)$ & $13(4.29)$ & $22(8.38)$ & $20.8(5.32)$ & $21.27(8.02)$ & $15.33(6.32)$ & $20.4(3.48)$ \\
\hline$>2$ years $M(\mathrm{SD})$ & $20.47(6.92)$ & $13(4.11)$ & $16.29(6.95)$ & $20.12(5.33)$ & $13.65(6.57)$ & $14.06(6.66)$ & $14.65(4.92)$ \\
\hline$t$ & $3.56^{\star \star \star}$ & 0 & $2.11^{*}$ & 0.36 & $2.95^{* *}$ & 0.55 & $3.77^{* * *}$ \\
\hline Mean difference & 9 & 0 & 5.71 & 0.68 & 7.62 & 1.27 & 5.75 \\
\hline \multicolumn{8}{|c|}{ CD4 cells level } \\
\hline$<350 / \mu \mathrm{l} M(\mathrm{SD})$ & $29.08(8.65)$ & $12.46(4.2)$ & $23.46(8.73)$ & $21.08(5.36)$ & $23.38(7.25)$ & $15.92(6.5)$ & $19.54(5.61)$ \\
\hline$>350 / \mu \mathrm{l} M(\mathrm{SD})$ & $21.68(6.89)$ & $13.37(4.15)$ & $15.89(6.05)$ & $20(5.27)$ & $13(5.73)$ & $13.79(6.41)$ & $15.84(4.34)$ \\
\hline$t$ & $2.57^{*}$ & -0.6 & $2.71^{*}$ & 0.56 & $4.32^{* * *}$ & 0.92 & 2 \\
\hline Mean difference & 7.39 & -0.91 & 7.57 & 1.08 & 10.38 & 2.13 & 3.7 \\
\hline
\end{tabular}


The Value subscale showed a statistically significant positive correlation with each measured aspect of psychosocial benefits.

The Importance subscale showed a statistically significant negative correlation with the following scales: Greater appreciation for life and Positive influence on others.

\section{Peripheral variables}

Variables related to antiretroviral therapy did not differentiate the results associated with personality changes in a statistically significant way. Relevant correlations were observed concerning the subjective assessment of the infection in terms of the duration of antiretroviral therapy and CD4 cell count.

The perception of infection was juxtaposed with the duration of antiretroviral therapy and the CD4 cell count (Table 6). Patients who had been treated for less than two years and those with CD4 cell count $<350 / \mu$ l showed significantly higher results in the following subscales: Threat, Obstacle/loss, and Harm. In addition, patients with shorter treatment duration showed significantly higher results in the Importance subscale.

\section{Discussion}

\section{Personality changes}

In the self-appraisals performed before and after the infection, the participants achieved low scores in the following scales: the need for self-understanding and understanding others, the need for nurturing others, and femininity.

Such scores are characteristic of people who find it more difficult to cope with stress and difficult situations. They value independence and isolation, avoid close relationships with others, are cautious about relationships and doubtful about other people's intentions, and present a defensive attitude. Their interests are often narrow, simple, and mundane. A high score in the Free Child scale is characteristic of people who cannot delay gratifications or are unable to strengthen their self-control. They can be perceived as funny, but also as aggressive. A retrospectively low score in the leadership scale is characteristic of people convinced that constant effort and self-discipline are pointless. They enjoy changes and diversity, and like to violate the limits only to check if they can bend or break the rules.

The score in the need for change scale is significantly lower after the infection. Patients look for stability and continuity. They avoid situations that are uncertain and risky. This is in accordance with reports from Iran, which state that HIV-infected patients showed a low need for new experiences [35].

The score rises in the Adapted Child scale. When facing the challenges of adulthood, patients receiving HAART therapy may present dependence and uncertainty. They fear direct confrontations and try to avoid them. They easily become disorganised under stress and in dangerous situations.
Patients receiving HAART therapy achieve significantly higher scores in the need for dependence scale. They pander to others, and place anonymity and lack of conflicts over success. This is in accordance with high scores achieved in the harm-avoidance and reward-addiction scales mentioned above [35]. These seem to be good predictors of effective antiretroviral therapy.

\section{The feeling of self-worth}

The feeling of self-worth plays a particular role in human personality. According to Maslow (1943), self-esteem is responsible for regulatory functions of the human psyche and constitutes a basic need of human personality. It defines personal resources of an individual and maintains the balance between the environment and oneself.

HIV-positive patients from Brazil have low self-esteem [36]. Eller et al. noticed such dependency in patients with symptoms of depression [37].

Conversely, Moskowitz did not notice differences in selfesteem between HIV-positive and HIV-negative patients. However, this can result from the methodology used, because data was gathered from homosexual and bisexual men during sex-parties [38].

During the research, we managed to determine the level of self-esteem in HIV-infected patients who have been receiving HAART therapy. The HIV-infected patients examined had the ACL score of 0.37. For comparison, anorectic girls scored 0.81, alcohol-addicted men scored 0.79 [39, 40], and a group of examined students scored 0.95 [41]. Considering the above, we came to the conclusion that patients receiving antiretroviral therapy tend to understate their level of self-esteem. Such a phenomenon may make it difficult to accept the role of a patient and may interfere with activities that promote health [42]. People with low self-esteem have already been described in the source literature [43]. They were characterised by negative self-attitude, low motivation to take action, and constant fear of failure. Such people were submissive, withdrawn, and had difficulties with interpersonal relationships. These personality traits are consistent with the interpretation of our own results regarding personality changes caused by the awareness of HIV infection.

\section{Post-traumatic growth}

Despite negative changes in the personality structure, people infected with HIV who had been receiving HAART therapy reported certain psychosocial benefits regarding personality development (improved character strength), improved interpersonal relationships, and changes in life philosophy. However, it must be pointed out that the HIV infection itself was not a positive experience nor was it necessary for such change to occur, thus it should not be identified with a feeling of happiness.

In the treatment group, post-traumatic growth and negative effects of distress occurred simultaneously. In the source 
literature it is assumed that, in general, these phenomena constitute separate entities [44]. Therefore, individuals experiencing psychosocial benefits may, at the same time, present a lower level of well-being and negative effects of psychological stress.

Few papers describe post-traumatic growth in HIV-infected patients.

Polish authors most often use the translated Polish version of the Post Traumatic Growth Inventory (PTGI) [45]. On average, HIV-infected patients achieve results that correspond to a sten score of 5-6. In the factorial analysis, the results were above the mean only in respect of appreciation for life [46, 47]. After having used the SL24 questionnaire, Kossakowska noticed (similarly to us) that thanks to the infection patients are mostly pleased with their interpersonal relationships and personality development. However, Kossakowska mentions that such benefits are not common [32].

In the latest paper by Chinese authors, more than $40 \%$ of respondents declare positive or definitely positive changes regarding interpersonal relationships, changes in life philosophy, and appreciation for life [48]. So far, the biggest effect of PTG was reported by Milam: 57\% respondents declared at least a moderate positive change since the diagnosis [49].

\section{Self-appraisal of the illness}

By analysing the strongest correlations between the perception of the HIV infection and personality traits, we can make a few observations. People who treat the infection as something particularly significant, which greatly disturbs their life balance, show a low level of personal adaptation. They present a high level of anxiety, are mentally strained, and tend to be moody. Patients with a low need for affiliation treat the infection as something unfair and harmful. In particular, they have difficulty in establishing satisfactory social relationships. People with a low need for independence are among those who perceive the infection as a loss. Such people tend to look for conventional and safe solutions in life. Treating the infection as something that has a deeper meaning is characteristic of people who achieved high scores in the masculinity scale and low scores in the need for self-abasing scale. This is characteristic of individuals who are firm, determined, assertive, and confident. The infection is treated as a challenge by people with a strong need for domination. They are self-assured and strong-willed individuals.

Few respondents perceive the infection as something beneficial. They treat it as an excuse, a chance of being released from their duties and responsibilities, or a chance to escape other problems. These patients achieved particularly low scores in the following scales: the need for self-understanding and understanding others, and femininity. This is characteristic of people who have narrow interests, have a negative attitude towards others, and cannot cope with stress. We were not able to confront these observations with the source literature findings because we failed to find any articles that touch upon similar correlations.

In the treatment group, the biggest number of significant, positive correlations occurred between psychosocial benefits and the HIV-infection appraisal in the positive aspect of perception, i.e. benefits and values. High positive correlations were also observed in the challenge scale. This can trigger an individual to mobilise their inner strength to fight the enemy (HIV). In such case the infection itself is treated as a life challenge. In order to complete this challenge, an individual has to employ all their resources in a flexible manner. Correlations in the negative aspect of HIV infection (i.e. threat and harm) were weaker and rarer. The Importance subscale, which treated the infection as a disturbance of life balance, showed a high, negative correlation with the greater appreciation for life aspect.

We found that age and sex did not have a statistically significant influence on the perception of the HIV infection in the participants.

Before creating the questionnaire, the authors of the Disease-Related Appraisals Scale had not conducted research on the measurement stability over time [34]. However, we have to assume that the perception of the HIV infection does not have to be stable. The assessment of the situation may evolve under one's own experiences, information provided by the physician, the media, as well as the opinions of others [50]. During the conducted research it was revealed that the duration of treatment and the CD4 cell count differentiate the way an individual perceives the HIV infection. Regarding the duration of treatment, patients who had been receiving HAART therapy for at least two years achieved significantly lower scores in the negative aspects of the infection (i.e. threat, obstacle, harm) than patients treated for a shorter time. Differences in the perception of the HIV infection were also present in the importance subscale (the biggest difference observed). Patients who had been receiving HAART therapy for more than two years found the infection to be less disturbing for their life balance than patients who had been receiving the therapy for a shorter time. In the treatment group, further significant differences in the perception of the infection were due to the CD4 cell count. Patients with a CD 4 cell count higher than $350 / \mu \mathrm{l}$ achieved significantly lower scores in the negative aspects of the infection (i.e. threat, obstacle, harm) than patients with the CD4 level below 350/ $\mu$ l.

\section{Limitations}

The examination of personality traits from before the infection is only retrospective. The study does not involve the data about the traumatic events that happened to the examined persons, other than HIV infection. We conducted our research on a small group of patients from only one region of Poland. The results should not be generalised. This paper is rather a basis for further research. Moreover, the cross-sectional study managed to detect the correlation, but was unable to clearly identify the cause and effect relationship. 


\section{Conclusions}

HIV infection can cause personality changes. HIV-infected patients who have been receiving HAART therapy have low self-esteem. HIV-infected patients who have been receiving HAART therapy may experience post-traumatic growth. There are correlations between the subjective assessment of the HIV infection and personality traits in patients who have been receiving HAART therapy. There are correlations between the subjective assessment of the HIV infection and the level of declared psychosocial benefits.

\section{Conflict of interest}

The authors declare no potential conflicts of interest with respect to the research, authorship, and/or publication of this article.

\section{References}

1. Global Health Observatory Data [Internet]. World Health Organization. 2018. Available at: http://www.who.int/gho/hiv/en (Accessed: 28.10.2018).

2. HIV i AIDS [Internet]. Główny Inspektorat Sanitarny. Available at: http://gis.gov.pl/zdrowie/promocja-zdrowia/profilaktyka-hiv-aids/ 488-hiv-i-aids (Accessed: 28.10.2018)

3. HIV i AIDS podstawowe informacje [Internet]. Krajowe Centrum do spraw AIDS. Available at: http://aids.gov.pl/hiv_aids/450 (Accessed: 28.10.2018).

4. Samji H, Cescon A, Hogg RS, Modur SP, Althoff KN, Buchacz K, et al. Closing the gap: increases in life expectancy among treated HIV-positive individuals in the United States and Canada. PLoS One 2013; 8: e81355.

5. Fabianova L. Psychosocial aspects of people living with HIV/AIDS. In: Social and Psychological Aspects of HIV/AIDS and their Ramifications. InTech Open, London 2011; 175-203.

6. Nightingale VR, Sher TG, Mattson M, Thilges S, Hansen NB. The effects of traumatic stressors and HIV-related trauma symptoms on health and health related quality of life. AIDS Behav 2011; 15: $1870-1878$.

7. Sherr L, Nagra N, Kulubya G, Catalan J, Clucas C, Harding R. HIV infection associated post-traumatic stress disorder and post-traumatic growth - a systematic review. Psychol Health Med 2011; 16: 612-629.

8. Safren SA, Gershuny BS, Hendriksen E. Symptoms of posttraumatic stress and death anxiety in persons with HIV and medication adherence difficulties. AIDS Patient Care STDS 2003; 17: 657-664.

9. Theuninck AC, Lake N, Gibson S. HIV-related posttraumatic stress disorder: investigating the traumatic events. AIDS Patient Care STDS 2010; 24: 485-491.

10. Johnson JG, Williams JB, Rabkin JG, Goetz RR, Remien RH. Axis I psychiatric symptoms associated with HIV infection and personality disorder. Am J Psychiatry 1995; 152: 551-554.

11. Sikkema K, Kochman A, DiFranceisco W, Bergholte J, Peterson M. Psychiatric co-morbidity in HIV secondary prevention. In: Milwaukee Conference, Medical College of Wisconsin 1999.

12. Penedo FJ, Gonzalez JS, Dahn JR, Antoni M, Malow R, Costa P, et al. Personality, quality of life and HAART adherence among men and women living with HIV/AIDS. J Psychosom Res 2003; 54: 271-278.

13. Burgess AP, Carretero M, Elkington A, Pasqual-Marsettin E, Lobaccaro C, Catalán J. The role of personality, coping style and social support in health-related quality of life in HIV infection. Qual Life Res 2000; 9: 423-437.
14. Ironson GH, O’Cleirigh C, Weiss A, Schneiderman N, Costa PT. Personality and HIV disease progression: role of NEO-PI-R openness, extraversion, and profiles of engagement. Psychosom Med 2008; 70: 245-253.

15. Szewczuk W. Słownik psychologiczny. Wiedza Powszechna, Warszawa 1985.

16. Maslow AH. A theory of human motivation. Psychological Review 1943; 50: 370-396.

17. Wrona-Polańska H. Psychoedukacja jako forma promocji zdrowia. Debata Edukacyjna 2013; 6: 78-88.

18. Tedeschi RG, Calhoun LG. The Posttraumatic Growth Inventory: measuring the positive legacy of trauma. J Trauma Stress 1996; 9: 455-471.

19. Tedeschi R, Park C, Calhoun L. Posttraumatic growth: positive changes in the aftermach of crisis. Mahwah, New Jersey 1998.

20. Zdankiewicz-Ścigała E. Trauma - proces i diagnoza: mechanizmy psychoneurofizjologiczne. Wydawnictwo Instytutu Psychologii PAN, 2002; 183.

21. Ho SMY, Chan MWY, Yau TK, Yeung RMW. Relationships between explanatory style, posttraumatic growth and posttraumatic stress disorder symptoms among Chinese breast cancer patients. Psychol Health 2011; 26: 269-285.

22. Folkman S, Moskowitz JT. Positive affect and meaning-focused coping during significant psychological stress. In: Hewstone M, Schut HAW, De Wit JBF, Van Den Bos K, Stroebe MS (eds.). The scope of social psychology: Theory and applications. Psychology Press, New York 2007; 193-208.

23. Leventhal $H$, Diefenbach $M$, Leventhal EA. Illness cognition: Using common sense to understand treatment adherence and affect cognition interactions. Cognitive Therapy and Research 1992; 16: 143-163.

24. Tedeschi RG, Calhoun LG. Posttraumatic growth: conceptual foundations and empirical evidence. Psychological Inquiry 2004; 15: 1-18.

25. Lazarus R, Folkman S. Stress, Appraisal, and Coping. Springer Publishing Company 1984; 460.

26. Lipowski ZJ. Physical illness, the individual and the coping processes. Psychiatry Med 1970; 1: 91-102.

27. Leventhal H. The Common Sense Representation of Illness Danger. Contributions to Medical Psychology1980; 2: 7-30.

28. Reekie J, Gatell JM, Yust I, Bakowska E, Rakhmanova A, Losso M, et al. Fatal and nonfatal AIDS and non-AIDS events in HIV-1-positive individuals with high CD4 cell counts according to viral load strata. AIDS 2011; 25: 2259-2268.

29. Gough HG, Heilbrun AB. The Adjective Check List Manual. Consulting Psychologists Press, 1983; 126.

30. Juros A, Oleś P. Struktura czynnikowa i skupieniowa Testu Przymiotnikowego ACL HG Gougha i AB Heilbruna (Przydatność dla diagnostyki psychologicznej). In: Z psychometrycznych problemów diagnostyki psychologicznej. Wydawnictwo Naukowe UAM, Poznań 1993.

31. Ostrowska K. Test Przymiotnikowy H. Gougha i A. Heilbruna: Opracowanie psychometryczne. ATK, Warszawa 1986.

32. Kossakowska M, Zielazny P. Obraz choroby i korzyści psychospołeczne u osób zakażonych wirusem HIV i chorych na AIDS. Postępy Psychiatrii i Neurologii 2013; 22: 177-185.

33. Bride OMC, Dunwoody L, Lowe-Strong A, Kennedy SM. Examining adversarial growth in illness: the factor structure of the Silver Lining Questionnaire (SLQ-38). Psychol Health 2008; 23: 661-678.

34. Janowski K, Steuden S, Kurylowicz J, Nieśpialowska-Steuden M. The Disease-Related Appraisals Scale: a tool to measure subjective perception of the disease situation. Biopsychosocial Aspects of Health and Disease 2009; 1: 108-125.

35. Salehi B, Zarinfar N, Noori H. The relationship between personality traits and AIDS in patients with human immunodeficiency virus. Asian J Psychiatr 2016; 21: 41-45.

36. Castrighini C, Gir E, Neves L, Reis R, Galvão M, Hayashido M. Depression and self-esteem of patients positive for HIV/AIDS in an inland city of Brazil. Retrovirology 2010; 7 (Suppl 1): P66. 
37. Eller LS, Rivero-Mendez M, Voss J, Chen W-T, Chaiphibalsarisdi P, Iipinge $\mathrm{S}$, et al. Depressive symptoms, self-esteem, HIV symptom management self-efficacy and self-compassion in people living with HIV. AIDS Care 2014; 26: 795-803.

38. Moskowitz DA, Seal DW. Self-esteem in HIV-positive and HIVnegative gay and bisexual men: implications for risk-taking behaviors with casual sex partners. AIDS Behav 2011; 15: 621-625.

39. Pawłowska B, Chuchra M. Akceptacja siebie i rodziców przez kobiety z jadłowstrętem psychicznym. Psychiatr Pol 2004; 38: 1031-1042.

40. Chuchra M, Ferenc A. Poziom samooceny i oceny żony przez mężczyzn uzależnionych od alkoholu. Roczniki Teologiczne 2007; 54: 169-178.

41. Wójtowicz P. Płeć psychologiczna a akceptacja siebie u studentów. KUL, Lublin 2005.

42. Wrona-Polańska H. Samoocena jako zasób sprzyjający zdrowiu. In: Zdrowie w cyklu życia człowieka. Wydawnictwo Uniwersytetu Łódzkiego, Łódź 2012; 89-107.

43. Henryk Kulas. Samoocena młodzieży [Internet]. Warszawa: Wydawnictwa Szkolne i Pedagogiczne; 1986 [cited 2018 Oct 28]. Available from: https://integro.ciniba.edu.pl/integro/191800848676/ kulas-henryk-edmund/samoocena-mlodziezy.

44. Tedeschi R, Calhoun L. Podejście kliniczne do wzrostu po doświadczeniu traumatycznym. In: Linley PA, Joseph S (eds.). Psychologia pozytywna w praktyce. PWN, Warszawa 2007; 230-248.

45. Ogińska-Bulik N, Juczyński Z. Rozwój potraumatyczny - charakterystyka i pomiar. Psychiatria 2010; 7: 129-142.

46. Ogińska-Bulik NJ. Ruminacje a negatywne i pozytywne skutki traumy u zakażonych HIV. Psychiatria 2016; 13: 8-16.

47. Rzeszutek M, Oniszczenko W, Gruszczyńska E. Satisfaction with life, Big-Five personality traits and posttraumatic growth among people living with HIV. Journal of Happiness Studies [Internet]. 2017. Available from: https://pbn.nauka.gov.pl/sedno-webapp/works/ 836044 (Accessed: 28.10.2018).

48. Lau JTF, Wu X, Wu AMS, Wang Z, Mo PKH. Relationships between illness perception and post-traumatic growth among newly diagnosed HIV-positive men who have sex with men in China. AIDS Behav 2018; 22: 1885-1898.

49. Milam J. Posttraumatic growth and HIV disease progression. J Consult Clin Psychol 2006; 74: 817-827.

50. Pilecka W. Przewlekła choroba somatyczna w życiu i rozwoju dziecka: problemy psychologiczne. Wydawnictwo Uniwersytetu Jagiellońskiego, Kraków 2002; 206. 